\title{
Effects of Seasonality on the Proximate Composition and Fatty Acid Profile in Cow Milk
}

\author{
Simionato J.I. ${ }^{1}$, Ana Paula Hiroki², Marly Sayuri Kats uda ${ }^{2}$, Mayka Reghiany Pe drão², \\ Lucia Fe licidade Dias ${ }^{2}$, Nilson Evelazio de Souza ${ }^{2, *}$
}

\begin{abstract}
${ }^{1}$ Departmentof Basic Studies and Instrumental, State University Southwest of Bahia, Praça Primavera, 40, Itap etinga, 45700- 000, Brazil ${ }^{2}$ Department of Food Technology, Technological University of Paraná, Rua dos Pioneiros, 3131, Londrina, 860356-370, Paraná, Brazil
\end{abstract}

\begin{abstract}
The present study investigated the influence of seasonality (summer and winter) on the proximate co mposition and on the amount of polyunsaturated fatty acids in milk fat. The amounts of lipid and protein were greater in the winter. The quantity of conjugated linoleic acid (CLA, rumenic acid, 18:2c9t11) in type B pasteurized milk (10.38 \pm 0.69 in summer and $7.44 \pm 0.82$ in winter) was higher than in type $C$ milk $(9.90 \pm 0.64$ in summer and $7.25 \pm 0.85$ in winter) in both seasons. The amount of trans linolelaidic acid (18:2n-6t), linoleic acid (18:2n-6) and linolenic acid (18:3n-3) had no variation between seasons and types of milk. Furthermore, the n-6/n-3 ratio of the milks analyzed after pasteurization has reduced significantly from $(\mathrm{p}<0.05) 7.50 \pm 0.85$ and $7.46 \pm 1.71$ in winter to $6.36 \pm 0.45$ and $6.72 \pm 0.61$ in summer for milk Type $\mathrm{C}$ and $\mathrm{B}$, respectively.
\end{abstract}

Keywords Linoleic Conjugated Acid, Rumenic Acid, Cow Milk, Seasonality

\section{Introduction}

Pasteurization is a thermal treatment applied to foods, including milk, to make them microbiologically safe for consumption. The most usual pasteurization process consists of raising temperature to $72^{\circ} \mathrm{C}$ for $15-20 \mathrm{~s}[1]$. Many researchers have studied how thermal processes affect the nutritional and organoleptic properties of foods. The pasteurization affects mainly protein structures[1-4]. However, few reports have demonstrated the effect of pasteurization on the composition and amounts of fatty acids [5].

Fat is one of the most abundant components of milk, and the most variable one. Its concentration and composition are more influenced by nutrition and environmental conditions than its other fractions [6, 7]. Conjugated linole ic acid (CLA) is a fatty acid present in ruminant milk fat. CLA isomers have different physiological effects. The biolog ical activity of two of them, 18:2 t10c12 and 18:2 c9t11, have already been demonstrated. The first is a potent inhibitor of the fat synthesis in milk and responsible for the redistribution of fat in the muscle, being able to reduce fat mass and increase lean mass. The other has antitumoral properties, reducing the incidence of breast cancer[7-12]. CLAs may be

* Corresponding author:

nesouza@ut fpr.edu.br (Nilson Evelazio de Souza)

Published online at http://journal.sapub.org/food

Copyright (C) 2012 Scientific \& Academic Publishing. All Rights Reserved produced synthetically and by the organism of ruminants in two ways: a) by incomplete biohydrogenation of dietary fatty acids and b) endogenously through the desaturation of trans-vaccenic fatty acid $(18: 1 n-7 t)$ by the enzyme stearoyl-CoA desaturase or $\Delta-9$-dessaturase present in mammary glands and in adipose tissue. As $18: 1 \mathrm{n}-7 \mathrm{t}$ is produced mainly by ruminal biohydrogenation, most CLA sources are ruminant products[13, 14]. Although the biological activities of c9t11 and t10c 12 had already been confirmed, other CLA isomers and their interactions need further studies to determine their possible effects on human health. Furthermore, the use of CLA isomers in a variety of functional foods is a possibility that must not be ignored. However, it is also necessary to investigate the quantities of the isomers present in different food matrices. The separation and quantification of these isomers in dairy products by gas chromatography is challenging. Determining their mean amounts will enable setting a safe intake limit that is simultaneous suitable for the ingestion of CLA and saturated fatty acids.

In this work, analyses on proximate composition and fatty acid quantification were performed focusing on conjugated linoleic acid (rumenic acid, 18:2c9t11), and omega-3 and omega-6 essential fatty acids in milks produced during two seasons (winter and summer) in Southern Brazil.

\section{Materials and Methods}




\subsection{Sampling}

Raw milk from 430 dairy cows aged from 3 to 7 years in lactation period (150 days) was analyzed. The animals were from 9 farms in Middle East of Paraná State and had excellent health. The animals were given feed complemented with high-quality forage ad libitum. Forage consisted of predominantly mo mbaça (Panicum maximum cv. Mombaça), tanzania (Panicum maximum cv. tanzania), and brachiaria (Brachiaria brizantha $\mathrm{cv}$. Marandu) grasses. The milk containers were immediately cooled to $4^{\circ} \mathrm{C}$ after sampling and the milk was pooled, pasteurized $\left(72^{\circ} \mathrm{C}\right.$ for 15-20 s) for milk type B (MB) and C (MC) and frozen.

Sampling were conducted in three consecutive weeks in January and July 2009 (summer and winter, respectively). The weekly samples $(n=81)$ were analy zed in triplicate.

\subsection{Chemical Analysis}

Moisture was determined according to the AOAC method[15] by oven heating $\left(105^{\circ} \mathrm{C}\right)$ and the ash content, by oven incineration $\left(600^{\circ} \mathrm{C}\right)$. Nitrogen was determined by the Kjeldahl method.

Total lipids were determined by the Folch[16] method with chloro form, methanol, and water in the rat io of $2: 1: 1$.

\subsection{Preparation of Fatty Acid Methyl Esters}

Fatty acid methyl esters were prepared as described by Bannon et al.[17] with modifications.

To a screw cap tube with approximately $150 \mathrm{mg}$ lipids was added $5.0 \mathrm{~mL}$ of $0.25 \mathrm{~mol} \mathrm{\textrm {L } ^ { - 1 }}$ sodium methoxide in methanol diethyl ether $(1: 1)$. The tube was stirred vigorously for about $3 \mathrm{~min}$. The mixture was added with 3.0 $\mathrm{mL}$ isooctane and approximately $15 \mathrm{~mL}$ of a saturated sodium chloride solution. The tube was vigorously stirred again and left at rest for phase separation. The supernatant was collected in labeled Eppendorf tubes for later chromatographic analysis. The original method used short heating under reflux after the addition of the transesterification reagent; however, this was not done to prevent the isomerization of the conjugated linoleic acid dienes.

\subsection{Chromatographic Analysis of Fatty Acid Methyl Es ters}

Fatty acid esters were analyzed in gas chromatographer CP-3380 (Varian, EUA) equipped with a flame ionization detector and fused silica capillary column CP-7420 (100 m, $0.25 \mathrm{~mm}$ and $0.39 \mu \mathrm{m}$ i.d., $100 \%$ bound cyanopropyl, Varian, EUA).

The flows of gas (White Martins) were $1.4 \mathrm{~mL} \mathrm{~min}^{-1}$ carrier gas $\left(\mathrm{H}_{2}\right), 30 \mathrm{~mL} \mathrm{m^{-1 }}$ auxiliary gas $\left(\mathrm{N}_{2}\right)$, and 30 and $300 \mathrm{~mL} \mathrm{~min}^{-1}$ for $\mathrm{H}_{2}$ and flame synthetic air, respectively. The sample split rate was $1 / 80$.

The injector and detector temperatures were both $240^{\circ} \mathrm{C}$. The column temperature was set at $65^{\circ} \mathrm{C}$ for $4 \mathrm{~min}$, followed by a first $16^{\circ} \mathrm{C} / \mathrm{min}$ ramp up to $185^{\circ} \mathrm{C}$ for $12 \mathrm{~min}$. The second ramp was set at $20^{\circ} \mathrm{C} / \mathrm{min}$ up to $235^{\circ} \mathrm{C}$, remain ing at this temperature for $14 \mathrm{~min}$. The total analysis time was $40 \mathrm{~min}$. The peak areas were determined with the software Star (Varian).

The injections were made in triplicate with injection volume of $2 \mu \mathrm{L}$. The fatty acids were identified based on the comparison of the retention times of the methyl esters with those of standards with geometric isomers c9t11 and t10c 12 of linoleic acid (189-19 and O-5626, Sigma, EUA).

The limits of detection and quantification were estimated at 0.148 and $0.476 \mathrm{mg} / \mathrm{g}$ lipids, respectively, according to the ACS[18] considering the signal/noise ratio equal to 3 and 10, respectively, from successive dilutions of a standard solution of methyl a rachidate.

\subsection{Quantification}

Total lipid fatty acids were measured in $\mathrm{mg} \mathrm{g}-1$ in relation to the internal standard, methyl tricosanoate $(23: 0)$, Sigma. Before transesterification, $1.00 \mathrm{~mL}$ of internal standard solution (1 mg mL $\mathrm{mL}^{-1}$ ) was added to each sample and the solvent was evaporated under $\mathrm{N}_{2}$ flow.

Fatty acid quantification was carried out after verifying the agreement between the theoretical and the experimental response factors.

The sample fatty acid concentrations were calculated according to Joseph and Ackman[19] following the equation 1:

C $\left(\mathrm{mgg}^{-1}\right)=$ A x.M23:0.FRT / A23:0.MA. FCT (Equation 1)

where:

$\mathrm{AX}=\mathrm{A}$ rea of the fatty acid methyl esters

A23:0 = Internal standard area

M23:0 = Mass of Internal standard added to the sample (mg)

MA $=$ sample mass $(\mathrm{g})$

FRT $=$ theoretical response factor of fatty acid methyl esters,

FCT = conversion factor to express results in $\mathrm{mg}$ fatty acids g-1 total lipids

Certified reference material (power milk) was used to confirm the accuracy of the method. The reference material (RM-8435) was obtained from the Canadian National Institute of Standards and Technology (NIST).

The accuracy of the method was confirmed by the analysis of the certified reference material (powder milk) with a quantitative recovery $(>80 \%)$ of the analyzed fatty acids. This method may be applied to the quantification of fatty acids in commercial samples[20].

\subsection{Statistical Analysis}

The results obtained were submitted to an analys is of variance (ANOVA) at 5\% probability and the means were compared by Tukey's test, using the software Statistica 7.0 [21].

\section{Results and Discussion}


Table 1 lists the results of the analysis of variance for the chemical composition of milk after pasteurization in the summer and winter.

Table 1. Proximate composition (\%) of type B (MB) and C (MC) pasteurized milk during different seasons

\begin{tabular}{|c|c|c|c|c|}
\hline & Moisture & Ash & Protein & Total Lipids \\
\hline \multicolumn{5}{|c|}{ Winter } \\
\hline $\mathrm{MC}$ & $88.20 \mathrm{a} \pm 0.04$ & $0.62 \mathrm{a} \pm 0.05$ & $3.43 \mathrm{ab} \pm 0.23$ & $3.39 \mathrm{a} \pm 0.23$ \\
\hline MB & $88.93 a \pm 1.38$ & $0.44 \mathrm{~b} \pm 0.03$ & $2.43 \mathrm{~cd} \pm 0.13$ & $3.08 \mathrm{ab} \pm 0.35$ \\
\hline \multicolumn{5}{|c|}{ Summer } \\
\hline $\mathrm{MC}$ & $\begin{array}{l}89.12 \mathrm{ab} \pm 0.1 \\
7\end{array}$ & $0.48 \mathrm{ab} \pm 0.03$ & $2.88 b c \pm 0.06$ & $3.04 \mathrm{bc} \pm 0.10$ \\
\hline MB & $90.23 \mathrm{a} \pm 0.49$ & $0.63 \mathrm{a} \pm 0.06$ & $2.53 \mathrm{~cd} \pm 0.25$ & $3.14 \mathrm{ab} \pm 0.17$ \\
\hline
\end{tabular}

Results in percentage as mean \pm standard deviation of 9 different milk producer $(\mathrm{n}=81)$. Means followed by different letters in the same row are significantly different by Tukey's Test at $5 \%$ probability between seasons

The content of lipid and protein were greater for the type $\mathrm{C}$ milk produced in the winter; for the type $\mathrm{B}$ milk there was no variation due to the standardization process for the fat content. The quantification of fatty acids for type $\mathrm{C}$ and type $\mathrm{B}$ milk produced during the winter and summer is presented in the Table 2. In total, 29 fatty acids were identified, primarily palmitic acid (14:0), oleic acid (18:1n-9), stearic acid (18:0) and myristic acid (14:0). The amounts of fatty acids were always high for milk produced in the summer, both the type $\mathrm{C}$ and $\mathrm{B}$.

As for the CLA (rumenic acid c9t11), the seasons had a significant influence on its content. Bugaud et al., (2001) suggested that the biohydrogenation in ruminants is lower in winter than in summer. The higher temperature may increase the activity of the isomerase, the enzyme that converts linoleic acid into CLA in the rumen, which is transported to tissues and mammary glands, or biohydrogenated to vaccenic acid by B. Fibriosolvens. Thus, appar ently, the transport of this substance to tissues and mammary glands is greater during warm season than its later biohydrogenation.

Herzallah et al.[5] reported a decrease in rumenic acid after pasteurization. Noteworthy, these authors used derivatization in acid medium with $\mathrm{HCl}$. It is known that the methylation by acid catalysis using $\mathrm{BF} 3, \mathrm{HCl}$, and $\mathrm{H}_{2} \mathrm{SO}_{4}$ favors the extensive isomerization of conjugated dienes and contributes to the formation of artefacts [11].

Table 2. Mean amounts ( $\mathrm{g} 100 \mathrm{~g}^{-1}$ milk fat) of polyunsat urated fatty acids in type $\mathrm{B}$ and type $\mathrm{C}$ pasteurized milk in different seasons

\begin{tabular}{|c|c|c|c|c|}
\hline \multirow[b]{2}{*}{ Fatty Acid } & \multicolumn{2}{|c|}{ Summer } & \multicolumn{2}{|c|}{ Winter } \\
\hline & $\begin{array}{c}\text { Pasteurized } \\
\text { type B }\end{array}$ & $\begin{array}{c}\text { Pasteurized } \\
\text { type } \mathrm{C}\end{array}$ & $\begin{array}{c}\text { Pasteurized } \\
\text { type B }\end{array}$ & Pasteurized type C \\
\hline $4: 0$ & $36.32 \mathrm{c} \pm 5.67^{*}$ & $37.32 \mathrm{c} \pm 2.67$ & $29.17 \mathrm{a} \pm 4.66$ & $23.65 b \pm 3.32$ \\
\hline $6: 0$ & $17.19 \mathrm{a} \pm 0.86$ & $14.51 \mathrm{~b} \pm 1.69$ & $18.68 \mathrm{a} \pm 2.57$ & $15.25 \mathrm{~b} \pm 1.95$ \\
\hline $8: 0$ & $9.79 \mathrm{a} \pm 0.48$ & $8.37 \mathrm{~b} \pm 0.92$ & $10.45 \mathrm{a} \pm 1.24$ & $9.03 \mathrm{~b} \pm 1.08$ \\
\hline $10: 0$ & $20.78 \mathrm{a} \pm 1.02$ & $17.77 \mathrm{~b} \pm 1.80$ & $22.00 \mathrm{a} \pm 2.31$ & $19.91 \mathrm{~b} \pm 2.47$ \\
\hline $11: 0$ & $2.45 \mathrm{a} \pm 0.20$ & $2.84 \mathrm{~b} \pm 0.39$ & $3.53 \mathrm{a} \pm 0.35$ & $3.20 \mathrm{~b} \pm 0.37$ \\
\hline $12: 0$ & $24.65 \mathrm{a} \pm 1.44$ & $21.32 \mathrm{~b} \pm 2.01$ & $25.69 \pm 2.22$ & $24.27 \pm 2.91$ \\
\hline $14: 0$ & $94.99 \mathrm{a} \pm 5.88$ & $84.55 \mathrm{~b} \pm 6.67$ & $93.62 \mathrm{a} \pm 7.57$ & $87.19 \mathrm{~b} \pm 5.72$ \\
\hline $14: \ln -11$ & $4.41 \mathrm{a} \pm 0.21$ & $4.15 \mathrm{~b} \pm 0.41$ & $4.37 \mathrm{a} \pm 0.44$ & $3.79 \mathrm{~b} \pm 0.23$ \\
\hline $14: \ln -9$ & $12.73 \mathrm{a} \pm 0.98$ & $11.31 \mathrm{~b} \pm 0.80$ & $12.10 \mathrm{a} \pm 1.18$ & $11.10 \mathrm{~b} \pm 0.58$ \\
\hline $14: \ln -7$ & $6.78 \mathrm{a} \pm 0.45$ & $6.17 \mathrm{~b} \pm 0.50$ & $5.54 \mathrm{a} \pm 0.38$ & $5.05 \mathrm{~b} \pm 0.38$ \\
\hline $15: 0$ & $11.83 \mathrm{a} \pm 0.75$ & $10.79 \mathrm{~b} \pm 0.97$ & $10.19 \pm 0.91$ & $10.41 \pm 0.58$ \\
\hline $15: \ln -7$ & $2.90 \mathrm{a} \pm 0.20$ & $2.66 \mathrm{~b} \pm 0.25$ & $2.82 \pm 0.24$ & $2.59 \pm 0.28$ \\
\hline $16: 0$ & $275.85 a \pm 17.13$ & $248.47 \mathrm{~b} \pm 20.45$ & $271.77 \mathrm{a} \pm 21.01$ & $261.85 \mathrm{a} \pm 17.74$ \\
\hline $16: \ln -11$ & $14.51 \mathrm{~b} \pm 0.88$ & $13.73 b \pm 1.29$ & $11.78 \mathrm{a} \pm 1.17$ & $9.76 b \pm 0.72$ \\
\hline $16: \ln -9$ & $11.80 \mathrm{a} \pm 1.09$ & $10.75 \mathrm{~b} \pm 0.88$ & $14.25 c \pm 0.81$ & $14.63 c \pm 0.83$ \\
\hline $16: \ln -7$ & $4.34 \mathrm{a} \pm 0.41$ & $4.10 \mathrm{a} \pm 0.35$ & $3.99 \mathrm{a} \pm 0.31$ & $3.70 \mathrm{~b} \pm 0.35$ \\
\hline i1 7:0 & $5.48 \mathrm{a} \pm 0.34$ & $4.92 \mathrm{~b} \pm 0.40$ & $4.88 \mathrm{~b} \pm 0.30$ & $4.67 \mathrm{~b} \pm 0.30$ \\
\hline $17: 0$ & $8.59 a \pm 0.56$ & $8.24 a \pm 0.86$ & $6.48 \mathrm{~b} \pm 0.58$ & $6.33 \mathrm{~b} \pm 0.96$ \\
\hline $17: \ln -7$ & $3.19 \mathrm{a} \pm 0.49$ & $2.56 \mathrm{~b} \pm 0.26$ & $2.93 a \pm 0.29$ & $2.98 \mathrm{a} \pm 0.36$ \\
\hline $18: 0$ & $113.45 \mathrm{c} \pm 6.01$ & $113.67 \mathrm{c} \pm 10.50$ & $103.65 \mathrm{a} \pm 9.02$ & $91.44 \mathrm{~b} \pm 8.38$ \\
\hline $18: 1 \mathrm{t}$ & $30.97 \mathrm{a} \pm 1.48$ & $30.75 a \pm 3.25$ & $21.66 \mathrm{~b} \pm 2.66$ & $21.51 \mathrm{~b} \pm 1.67$ \\
\hline $18: \ln -9$ & $215.11 \mathrm{a} \pm 13.26$ & $213.01 \mathrm{a} \pm 19.76$ & $223.14 a \pm 17.69$ & $203.27 \mathrm{~b} \pm 19.06$ \\
\hline $18: \ln -7$ & $4.05 a \pm 0.69$ & $4.34 \mathrm{a} \pm 0.60$ & $2.44 \mathrm{~b} \pm 0.34$ & $2.19 \mathrm{~b} \pm 0.27$ \\
\hline $18: 2 \mathrm{n}-6 \mathrm{t}$ & $9.65 \pm 0.68$ & $9.84 \pm 1.01$ & $9.70 \pm 1.69$ & $9.77 \pm 1.56$ \\
\hline $18: 2 n-6$ & $13.59 \pm 1.12$ & $13.81 \pm 1.01$ & $14.96 \pm 1.66$ & $15.59 \pm 2.30$ \\
\hline $18: 3 n-3$ & $3.87 \pm 0.32$ & $3.66 \pm 0.44$ & $3.32 \pm 0.43$ & $3.15 \pm 0.40$ \\
\hline $18: 2 \mathrm{c} 9 \mathrm{t} 11$ & $10.38 \mathrm{a} \pm 0.69$ & $9.90 \mathrm{a} \pm 0.64$ & $7.44 \mathrm{~b} \pm 0.82$ & $7.25 \mathrm{~b} \pm 0.85$ \\
\hline SFA & $616.50 \mathrm{a} \pm 19.49$ & $563.57 \mathrm{a} \pm 24.35$ & $600.11 \mathrm{a} \pm 24.93$ & $553.91 \mathrm{~b} \pm 21.21$ \\
\hline MUFA & $310.40 \mathrm{a} \pm 13.49$ & $302.04 a \pm 20.13$ & $304.38 \mathrm{a} \pm 18.01$ & $277.08 \mathrm{~b} \pm 19.19$ \\
\hline PUFA & $37.54 \pm 1.52$ & $35.33 \pm 1.63$ & $35.15 \pm 2.54$ & $30.93 \pm 2.94$ \\
\hline$n-6$ & $23.30 \pm 1.31$ & $23.12 \pm 1.43$ & $24.67 \pm 2.37$ & $25.95 \pm 2.78$ \\
\hline$n-3$ & $3.84 \pm 0.32$ & $3.66 \pm 0.44$ & $3.32 \pm 0.43$ & $3.17 \pm 0.40$ \\
\hline PUFA/SFA & $0.06 \pm 0.00$ & $0.06 \pm 0.00$ & $0.06 \pm 0.00$ & $0.06 \pm 0.00$ \\
\hline$n-6 / n-3$ & $6.36 a \pm 0.45$ & $6.72 a \pm 0.61$ & $7.50 \mathrm{~b} \pm 0.85$ & $7.42 \mathrm{~b} \pm 0.94$ \\
\hline
\end{tabular}

Results in percentage as mean \pm standard deviation of 9 different milk producer $(n=81)$. Means followed by different letters in the same row are significantly different by Tukey's between seasons 
In relation to the trans-octadecadienoic fatty acids, the amount of conjugated linoleic acids and linolelaidic acid has increased, and the quantity of cis-linoleic fatty acids decreased during the study seasons, from summer to winter. Herzallah et al. [5] observed no significant increase in the amount of trans isomers in milk submitted to conventional heating, except when heated to $63^{\circ} \mathrm{C}$ for $30 \mathrm{~min}$ and milk microwaved for 5 minutes, which increased in a range of 19-31\%. Santos Jr et al. [22] registered higher amounts of rumenic acid (conjugated linoleic acid - CLA) in the raw milk, and lower amount in pasteurized milk, compared with the present study, evidencing that the pasteurization reduces the amount of CLA. Test at $5 \%$ probability. $\Sigma$ SFA $=$ summation of saturated fatty acids; $\Sigma$ MUFA $=$ summation of monounsaturated fatty acids; $\Sigma$ PUFA $=$ summation of polyunsaturated fatty acids.

Table 2 shows that the lowest $n-6 / n-3$ ratios were found in pasteurized milk produced in the summer. Clinical studies in the last decade pointed out the need of reducing the $n-6 / n-3$ ratio. The English health department [23] recommends that the n-6/n-3 ratio should be below 4 . Simopoulos [24] suggested values between 5 and 10. In France and Switzerland, the recommended value is 5.1. At last, it is observed a convergence to values between 4 and $5.1[25]$.

\section{Conclusions}

In summary, the amount of CLA (rumenic acid) was higher in the summer, and the amount of trans linolelaid ic acid (18:2n-6t), linoleic acid (18:2n-6) and linolenic acid (18:3n-3) had no variation between seasons neither between types of milk.

\section{REFERENCES}

[1] Pereda, J.A., Jaramillo, D.P., Quevedo, J.M., Ferragut, V., Guamis, B., Trujillo, A.J. Characterization of volatile compounds in ultra-high-pressure homogenized milk. International Dairy Journal, 18, 826-834, 2008.

[2] Giroux, H.J., St-Amant, J.B., Fustier, P., Chapuzet, J-M., Britten, M. Effect of electroreduction and heat treatments on oxidative degradation of a dairy beverage enriched with poly unsaturated fatty acids. Food Research International, 41, 145-153, 2008.

[3] Raynal-Ljutovac, K., Park, Y.W., Gaucheron, F., Bouhallab, S. Heat stability and enzymatic modifications of goat and sheep milk. Small Ruminant Research, 68, 207-220, 2007.

[4] Rynnea, N.M., Beresforda, T.P., Kellyb, A.L., Guineea, T.P. Effect of milk pasteurization temperature and in situ whey protein denaturation on the composition, texture and heat-induced functionality of half-fat Cheddar cheese. International Dairy Journal, 14, 989-1001, 2004.
[5] Harzallah, S.M., Humeid, M.A., Al-Ismail, K.M. Effect of Heating and Processing Methods of Milk and Dairy Products on Conjugated Linoleic Acid and Trans Fatty Acid Isomer Content. Journal of Dairy Science, 88, 1301-1310, 2005.

[6] Collomb, M., Bütikofer, U., Sieber, R., Jeangros, B., Bosset, J.O. Composition of fatty acids in cow's milk fat produced in the lowlands, mountains and highlands of Switzerland using high-resolution gas chromatography. International Dairy Journal, 12, 649-659, 2002.

[7] Sieber, R; Collomba, M.; Aeschlimann, A.; Jelen, P.; Eyer, H. Impact of microbial cultures on conjugated linoleic acid in dairy products - a review. International Dairy Journal, 14, $1-15,2004$.

[8] Parodi, P.W. (1994). Conjugated linoleic acid: an anticarcinogenic fatty acid present in milk. Australian Dairy Technology, 49, 93-97.

[9] Roach, J.A.G.; Mossoba, M.M.; Yurawecz, M.P., Kramer, J.K.G. Chromatographic separation and identification of conjugated linoleic acid isomers. Analytica Chimica Acta, 465, 207-226, 2002.

[10] Seçkin K.A.; Gursoy, O; Kinik O.; Akbulut, N. Conjugated linoleic acid (CLA) concentration, fatty acid composition and cholesterol content of some Turkish dairy products. Food Science and Technology, 38, 909-915, 2005.

[11] Fuente, M.A. de la; Luna, P.; Juarez, M. Chromatographic techniques to determine conjugated linoleic acid isomers. Trends in Analytical Chemistry, 25, 917-926, 2006.

[12] Ou, L., Ip, C., Lisafeld, B., Ip. M.M. Conjugated linoleic acid induces apoptosis of murine mammary tumor cells via Bcl-2 loss. Biochemical and Biophysical Research Communications, 356, 1044-1049, 2007.

[13] Buccione, A., Antongiovanni, M., Petacchi, F., Mele, M., Serra, A., Secchiari, P., Benvenuti, D. Effect of dietary fat quality on C18:1 fatty acids and conjugated linoleic acid production: An in vitro rumen fermentation study. Animal Feed Science and Technology, 127, 268-282, 2006.

[14] Martin, C.A. Milinsk, M.C., Visentainer, J.V., Matsushita, M., Souza, N.E. Trans fatty acid-forming processes in foods: a rewiew. Annals of the Brazilian Academy of Sciences, 79, 343-350., 2007.

[15] Cunniff, P.A. Official Methods of Analysis of AOAC International. 16th ed. Arlington: Association of Official Analitical Chemists, 1998.

[16] Folch, J., Lees, M., Stanley, G.H.S. A simple method for the isolation and purification of total lipids from animal tissues. The Journal of biolo gical chemistry, 226, 497-509, 1957.

[17] Bannon, C.D., Breen, G.J., Craske, J.D., Hai, N.T., Harper, N.L., O'Rourke, K.L. Analysis of fatty acid methyl esters with high accuracy and reliability. Journal of Chromatography, 247, 71-89, 1982.

[18] [18] ACS-American Chemical Society Guidelines for data acquisition and data quality evaluation in Environmental Chemistry. Analy tical Chemistry, 52, 2242-2249, 1980.

[19] Joseph, J. D., Ackman, R. G., Capillary column gas chromatography method for analy sis of encap sulated fish oil and fish oil ethyl esters: collaborative study. Journal of Association of Official Analytical Chemical International, 75 (3), 488-506, 1992. 
[20] Simionato, J. I., Garcia, J. C., Santos, G. T., Oliveira, C. C. Visentainer, J. V., de Souza, N. E. Validation of the Determination of Fatty Acids in Milk by Gas Chromatography. Journal of the Brazilian Chemical Society, 21, 520-524, 2010.

[21] Statsoft, Statistica 7.0 software. Tucksa, USA, 2004.

[22] Santos Jr, O. O., Pedrão, M. R., Dias, L. F., Paula, L. N. Coro, F. A. G., de Souza N. E. (Fatty Acid Content of Bovine Milkfat From Raw Milk to Yoghurt. American Journal of Applied Sciences, 9, 1300 - 1306, 2012.
[23] HMSO. England Departament of Health. Nutritional Aspects of Cardiovascular Disease. Health and Social Subjects, 46, 1-15, 1994.

[24] Simopoulos, A.P. Evolutionary aspects of diet, the omega-6/omega-3 ratio and genetic variation: nutritional implications for chronic diseases. Biomedecine \& Pharmacotherapy, 60, 9, 502-507, 2006.

[25] Martin, C.A.; Almeida, V.V.; Ruiz, M.R.; Visentainer, J.E.L.; Matshushita, M.; Souza, N.E.; Visentainer, J.V. Ácidos graxos poliinsaturados omega-3 e ômega-6: importância e ocorrência em alimentos. Brazilian Journal of Nutrition, 19, 761-770, 2006. 